\title{
Synthesis, Chemical Structure Elucidation and Biological Studies on the Effect of Some Vital Metal Ions on Lisinopril
}

\author{
M. Zaky, ${ }^{1}$ Mohamed Y. El-Sayed1, ${ }^{1,2}$, Samy M. El-Megharbel, ${ }^{1,3}$ Sameh Abo Taleb, ${ }^{1}$ and Moamen S. \\ Refat $^{3,4}$ \\ ${ }^{1}$ Department of Chemistry, Faculty of Science, Zagazig University, Egypt \\ 2 Faculty of Applied Medical Science, Al Jouf University-Al Qurayate \\ 3 Department of Chemistry, Faculty of Science, Taif University, 888 Taif, Kingdom Saudi Arabia \\ ${ }^{4}$ Department of Chemistry, Faculty of Science, Port Said, Port Said University, Egypt msrefat@yahoo.com
}

Received October $28^{\text {th }}, 2013$; Accepted February $12^{\text {th }}, 2014$

\begin{abstract}
Complexes of lisinopril as a pharmaceutical ligand with $\mathrm{Ca}(\mathrm{II}), \mathrm{Mg}(\mathrm{II}), \mathrm{Zn}(\mathrm{II}), \mathrm{Fe}(\mathrm{III})$ and $\mathrm{VO}(\mathrm{II})$, were synthesized and characterized by microanalysis, conductance, infrared and thermogravimetric (TGA/DTG and DTA) measurements. The lisinopril ligand acts as a monodentate feature via one carboxylate oxygen atom. Lisinopril and their complexes have been checked against some kinds of bacteria and fungi which gave a significant effect. The kinetic thermodynamic parameters such as: activation of $\mathrm{E}^{*}, \Delta \mathrm{H}^{*}, \Delta \mathrm{S}^{*}$ and $\Delta \mathrm{G}^{*}$ were estimated using Coats and Redfern as well as Horowitz-Metzger equations. Key words: Lisinopril complexes, Infrared spectra, electronic spectra, thermal analysis and antimicrobial activity.
\end{abstract}

\section{Introduction}

Metal ions are required for many critical functions in humans [1-5]. Scarcity of some metal ions can lead to disease. Wellknown examples include pernicious anemia resulting from iron deficiency, growth retardation arising from insufficient dietary zinc, and heart disease in infants owing to copper deficiency [1]. Metals and metal complexes have played key role in the development of modern chemotherapy [6]. For example, anticancer platinum drugs appear in more chemotherapy regimens than any other class of anticancer agents and have contributed substantially to the success achieved in treating cancer over the past three decades. This is allowing the drug to be released in a controlled fashion or at specific location [7]. This approach may lead to the rescue of drugs that have failed because of poor pharmacology or high toxicity. For example, complexation of non-steroidal anti-inflammatory drugs to copper overcomes some of the gastric side effects of these drugs [8]. The release of cytotoxins such as nitrogen mustards from redox-active metals such as cobalt in the hypoxic regions of solid tumors has the potential to improve drug activity and reduce toxicity [9]. The metal based drugs are also being used for the treatment of a variety of ailments viz. diabetes, rheumatoid arthritis, inflammatory and cardiovascular diseases as well as diagnostic [10-12]. A number of drugs and potential pharmaceutical agents also contain metal-binding or metal-recognition sites, which were influence on their bioactivities [13-24]. Numerous examples of these metallodrugs and metallopharmaceuticals and their actions can be found in the literature, for instance: (a) several
Resumen. En este trabajo se sintetizaron los complejos de lisinopril como ligando farmacéutico con iones $\mathrm{Ca}(\mathrm{II}), \mathrm{Mg}(\mathrm{II}), \mathrm{Zn}$ (II), $\mathrm{Fe}(\mathrm{III})$ and VO(II). Los complejos obtenidos fueron caracterizados por microanálisis, mediante mediciones de conductividad, espectros de absorción IR y termogravimetría (TGA/DTG y DTA). El lisinopropil actúa como el ligando monodentado mediante el átomo de oxígeno del grupo carboxilo. La actividad biocida del lisinopril y sus complejos fue demostrada mediante ensayos con diferentes cepas de bacterias y micro hongos. Se estimaron parámetros cinéticos y termodinámicos tales como activación de $\mathrm{E}^{*}, \Delta \mathrm{H}^{*}, \Delta \mathrm{S}^{*}$ y $\Delta \mathrm{G}^{*}$, utilizando ecuaciones de Coats y Redfern y también de Horowitz-Metzger.

Palabras clave: Complejos de lisinopril, espectros de infrarrojo, espectros electrónicos, termoanálisis, actividad antimicrobiana.

anti-inflammatory drugs, such as aspirin and its metabolite salicylglycine [13-16], suprofen [17], and paracetamol [18]; (b) the potent histamine-H2-receptor antagonist cimetidine [19] can form complexes with $\mathrm{Cu}^{2+}$ and $\mathrm{Fe}^{3+}$, and the histidine blocker antiulcer drug famotidine can also form stable complex with $\mathrm{Cu}^{2+}[20,21]$; (c) the anthelmintic and fungistatic agent thiabendazole, which is used for the treatment of several parasitic diseases, forms a $\mathrm{Co}^{2+}$ complex of 1:2 metal to drug ratio [22] (d) the $\mathrm{Ru}^{2+}$ complex of the anti-malaria agent chloroquine exhibits an activity two to five times higher than the parent drug against drug-resistant strains of Plasmodium faciparum [23]. However, it is known that some drugs act as potential ligands, a lot of studies are being carried out to ascertain how metal binding influences the activities of the drugs [24]. Metal-organic frameworks are not only stems from their tremendous potential applications in areas such as catalysis, molecular adsorption, magnetism, nonlinear optics, and molecular sensing, but also from their novel topologies and intriguing structural diversities [25-28]. On the other hand, many organic drugs, which possess modified pharmacological and toxicological properties administered in the form of metallic complexes [29], have the potential to act as ligands and the resulting metal-drug complexes are particularly important both in coordination chemistry and biochemistry [30-34] however, the study of metal-drug complexes is still in its early stages, thus representing a great challenge in current synthetic chemistry and coordination chemistry.

Lisinopril $N^{2}$-[(1S)-1-carboxy-3-phenylpropyl]-L-lysyl-Lproline is a lysine analog of enalaprilat. It is a long-acting, nonsulfhydryl angiotensin-converting enzyme inhibitor (For- 
mula 1), treatment of hypertension and congestive heart failure in daily dosages of 10-80 $\mathrm{mg}$ [35]. Pharmacological activity of lisinopril has been proved in previous experimental and clinical studies [36-37]. Historically, lisinopril was the third angiotensin-converting enzyme inhibitor (after captopril and enalapril) and was introduced into therapy in the early 1990. A number of properties distinguish it from other angiotensin-converting enzyme inhibitors: It is hydrophilic, has a long half-life and tissue penetration, and is not metabolized by the liver. Successful clinical trials in essential hypertension, renovascular hypertension and congestive heart failure have been conducted with lisinopril. Lisinopril is not significantly metabolized in humans; the absorbed drug is primarily excreted unchanged in urine. Peak serum concentrations of lisinopril are reached in about $6 \mathrm{~h}$ after administration. Mean maximum serum concentrations of lisinopril are about $80-140 \mathrm{ng} / \mathrm{mL}$ after a single oral dose of $20 \mathrm{mg}$ [38]. Its indications, contraindications and side effects are as those for all angiotensin-converting enzyme inhibitors. Lisinopril is a subject of monograph in the United States Pharmacopoeia, which recommends an HPLC method for its analysis [39]. A variety of analytical techniques have been developed for the determination of lisinopril in pharmaceutical preparations, such as HPLC [40], GC [41], capillary electrophoresis [42-43], spectrophotometry [44-45], spectroflurimertric [40], micellar electrokinetic chromatography [46] and polarographic [45]. Techniques have been described for determination of lisinopril in biologic fluids including GC [47], HPLC [48], LC-MS [49], fluoroimmunoassay [50], radioimmuoassay [51], fluorozmatic assay [52] and ion selective electrodes [53].

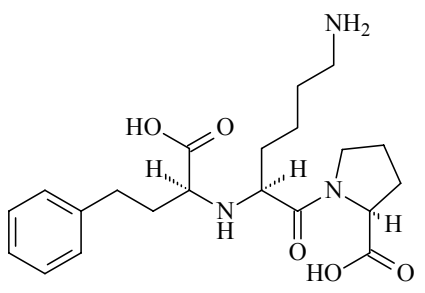

Formula 1. Structure of lisinopril (Lis).
Lisinopril possesses are poor in electromagnetic absorbance due to week benzene chromophore; as a consequence, poor sensitivity can be achieved by UV spectrophotometric method. Therefore, most of these assays employ pre-column derivatization reactions to enhance the determination sensitivity. However, the preparation of derivatives is a time consuming procedure, and the derivatization frequently generates products that are unstable. Moreover, peak splitting owing to slow cistrans isomerization may exist in the RP-HPLC [54]. GC and LC with mass spectrometric detection were widely applied to determination in biological fluids. In the literature survey, the synthesis and characterization of anti-hypertensive drugs complexes with some metal ions have been described [55-57]. The scope of this article is to discuss the coordination behavior of some of vital metal ions like $\mathrm{Ca}(\mathrm{II}), \mathrm{Mg}(\mathrm{II}), \mathrm{Zn}(\mathrm{II}), \mathrm{Fe}(\mathrm{III})$ and $\mathrm{VO}(\mathrm{II})$ with one of common blood pressure drug as lisinopril. The antibacterial and antifungal activities of lisinopril and its complexes were also evaluated.

\section{Results and Discussion}

The reactions of lisinopril (Lis) with the metal ions $\mathrm{Ca}(\mathrm{II})$, $\mathrm{Mg}(\mathrm{II}), \mathrm{Zn}(\mathrm{II}), \mathrm{Fe}(\mathrm{III})$ and $\mathrm{VO}(\mathrm{II})$ gave a colored solid complexes in moderate to good yields $(60-80 \%)$. The physical and analytical data, colors, percentage (carbon, hydrogen and nitrogen) and melting/decomposition temperatures of the compounds are presented in Table 1. The found and calculated percentages of elemental analysis $\mathrm{CHN}$ are in a well agreement with each other and prove the suggested molecular formula of the resulted lisinopril complexes. The complexes have high melting points $(226-266){ }^{\circ} \mathrm{C}$. The lisinopril ligand behaves as monodentate ligand and coordinates to the metal ions via one the oxygen atom of the carboxylate group. The isolated lisinopril complexes are 1:1 molar ratio of (M:Lis) where $\mathrm{M}=\mathrm{Ca}(\mathrm{II})$, $\mathrm{Mg}(\mathrm{II}), \mathrm{Zn}(\mathrm{II}), \mathrm{Fe}(\mathrm{III})$ and $\mathrm{VO}(\mathrm{II})$.

Molar conductivities: The molar conductivity values for the $\mathrm{Ca}(\mathrm{II}), \mathrm{Mg}(\mathrm{II}), \mathrm{Zn}$ (II), $\mathrm{Fe}(\mathrm{III})$ and $\mathrm{VO}(\mathrm{II})$ complexes of lisinopril in DMSO solvent $\left(1.00 \times 10^{-3} \mathrm{M}\right)$ were found to be in the range $5-27 \Omega^{-1} \cdot \mathrm{cm}^{2} \cdot \mathrm{mol}^{-1}$ at $25^{\circ} \mathrm{C}$, suggesting them to

Table 1. Elemental analysis and physical data of lisinopril complexes.

\begin{tabular}{|c|c|c|c|c|c|c|c|c|c|c|c|c|}
\hline \multirow[t]{2}{*}{ Complex } & \multirow{2}{*}{$\begin{array}{l}\text { M. wt. } \\
\text { (g/mol) }\end{array}$} & \multirow[t]{2}{*}{$\mathrm{mp} /{ }^{\circ} \mathrm{C}$} & \multirow[t]{2}{*}{ color } & \multicolumn{2}{|c|}{$\% \mathrm{C}$} & \multicolumn{2}{|c|}{$\% \mathrm{H}$} & \multicolumn{2}{|c|}{$\% \mathrm{~N}$} & \multicolumn{2}{|c|}{$\% \mathrm{M}$} & \multirow{2}{*}{$\begin{array}{l}\Lambda \mathrm{m}\left(\Omega^{-1}\right. \\
\left.\mathrm{cm}^{2} \mathrm{~mol}^{-1}\right)\end{array}$} \\
\hline & & & & Calc. & found & Calc. & found & Calc. & found & Calc. & found & \\
\hline $\begin{array}{l}{\left[\mathrm{Ca}(\mathrm{Lis})(\mathrm{Cl})\left(\mathrm{NH}_{4}\right)\left(\mathrm{H}_{2} \mathrm{O}\right)_{4}\right] \cdot 2 \mathrm{H}_{2} \mathrm{O}} \\
\left(\mathrm{C}_{21} \mathrm{H}_{45} \mathrm{~N}_{4} \mathrm{O}_{11} \mathrm{Cl} \mathrm{Ca}\right)\end{array}$ & 604.5 & 233 & Yellow & 41.69 & 42.23 & 7.44 & 7.25 & 9.26 & 9.49 & 6.62 & 6.60 & 22 \\
\hline $\begin{array}{l}{\left[\mathrm{Mg}(\mathrm{Lis})(\mathrm{Cl})\left(\mathrm{NH}_{4}\right)\left(\mathrm{H}_{2} \mathrm{O}\right)_{4}\right] \cdot 9 \mathrm{H}_{2} \mathrm{O}} \\
\left(\mathrm{C}_{21} \mathrm{H}_{59} \mathrm{~N}_{4} \mathrm{O}_{18} \mathrm{Cl} \mathrm{Mg}\right)\end{array}$ & 714.5 & 240 & Yellow & 35.27 & 35.22 & 8.26 & 8.28 & 7.84 & 7.06 & 3.36 & 3.24 & 27 \\
\hline $\begin{array}{l}{\left[\mathrm{Zn}(\mathrm{Lis})\left(\mathrm{SO}_{4}\right)\left(\mathrm{NH}_{4}\right)\left(\mathrm{H}_{2} \mathrm{O}\right)_{3}\right] \cdot 9 \mathrm{H}_{2} \mathrm{O}} \\
\left(\mathrm{C}_{21} \mathrm{H}_{57} \mathrm{~N}_{4} \mathrm{O}_{21} \mathrm{~S} \mathrm{Zn}\right)\end{array}$ & 798.4 & 234 & $\begin{array}{l}\text { Pale } \\
\text { brown }\end{array}$ & 31.56 & 31.35 & 7.14 & 7.10 & 7.01 & 7.88 & 8.19 & 8.04 & 7 \\
\hline $\begin{array}{l}{\left[\mathrm{Fe}(\mathrm{Lis})\left(\mathrm{NO}_{3}\right)_{2}\left(\mathrm{NH}_{4}\right)\left(\mathrm{H}_{2} \mathrm{O}\right)\right] \cdot \mathrm{H}_{2} \mathrm{O}} \\
\left(\mathrm{C}_{21} \mathrm{H}_{37} \mathrm{~N}_{6} \mathrm{O}_{13} \mathrm{Fe}\right)\end{array}$ & 637 & 266 & Brown & 39.56 & 40.28 & 5.81 & 5.47 & 13.19 & 13.60 & 8.79 & 8.51 & 5 \\
\hline $\begin{array}{l}{\left[\mathrm{VO}(\mathrm{Lis})\left(\mathrm{SO}_{4}\right)\left(\mathrm{NH}_{4}\right)_{2}\right] \cdot 4 \mathrm{H}_{2} \mathrm{O}} \\
\left(\mathrm{C}_{21} \mathrm{H}_{45} \mathrm{~N}_{5} \mathrm{O}_{13} \mathrm{~S} \mathrm{VO}\right)\end{array}$ & 674 & 226 & $\begin{array}{l}\text { Dark } \\
\text { green }\end{array}$ & 37.39 & 36.63 & 6.68 & 6.53 & 10.39 & 10.78 & 9.94 & 9.87 & 8 \\
\hline
\end{tabular}


be non-electrolytes [58] as shown in Table 1. Hence the molar conductance values indicate that no ions are present outside the coordination sphere so the $\mathrm{Cl}^{-}, \mathrm{SO}_{4}{ }^{2-}$ and $\mathrm{NO}_{3}{ }^{-}$ions may be exhibit inside the coordination sphere or absent. The obtained results were strongly matched with the qualitative analyses where $\mathrm{Cl}^{-}, \mathrm{SO}_{4}{ }^{2-}$ and $\mathrm{NO}_{3}{ }^{-}$ions are detected in case of $\mathrm{Ca}(\mathrm{II})$, $\mathrm{Mg}(\mathrm{II}), \mathrm{Zn}(\mathrm{II}), \mathrm{Fe}(\mathrm{III})$ and $\mathrm{VO}(\mathrm{II})$ complexes after degradation of these complexes by using nitric acid then precipitation of $\mathrm{Cl}^{-}$and $\mathrm{SO}_{4}{ }^{2-}$ by addition of $\mathrm{AgNO}_{3}$ and $\mathrm{BaCl}_{2}$ solutions, respectively to the solutions of the mentioned complexes were detected by using infrared spectral data. The low conductivity values [59] are in agreement with the low solubility of the above complexes in water, alcohol, chloroform, acetone and most of organic solvents. On other hand, they are soluble in DMSO, DMF and concentrated acids.

Electronic absorption spectra of lisinopril complexes: Electronic spectra of the lisinopril complexes were recorded in the 200-900 $\mathrm{nm}$ regions in DMSO. There are three detected absorption bands at (225 and 270) and $320 \mathrm{~nm}$ in the electronic spectrum of the free lisinopril ligand, these bands assigned to $\pi$ $\pi^{*}$ and $n-\pi^{*}$ transitions, respectively. These transitions occur in case of unsaturated hydrocarbons, which contain carbon atom attached with oxygen atoms as in carboxylic and ketone groups [60]. These bands of the free lisinopril ligand are bathochromically affected (red shifted) clearly in the electronic spectra of the $\mathrm{Fe}$ (III) and $\mathrm{VO}$ (II) complexes which show absorption bands at (259 and 325 shoulder) $\mathrm{nm}$ for $\mathrm{Fe}(\mathrm{III})$ complex and at (257 and 326 shoulder) $\mathrm{nm}$ for $\mathrm{VO}$ (II) complex which assigned to $\pi-\pi^{*}$ and $n-\pi^{*}$ transitions, respectively. This bathochromically change in the spectra of Fe(III) and VO(II) complexes indicated the association metal-to-ligand chelations. These results are clearly in accordance with the results of FT-IR and ${ }^{1} \mathrm{H}-\mathrm{NMR}$ spectra.

Infrared spectra of lisinopril complexes: The infrared spectral data of lisinopril and its complexes under investigation are recorded in Table 2. The spectra are similar but there are some differences which could give indication on the type of coordination. The infrared spectra of the free lisinopril show two broad bands observed at 3554 and $3396 \mathrm{~cm}^{-1}$, these bands are assigned due to the $v_{\mathrm{as}}(\mathrm{OH})$ and $v_{\mathrm{s}}(\mathrm{OH})$ stretching vibration of the -OH group. The infrared spectral bands of lisinopril complexes have a broad band's observed at $3400-3416 \mathrm{~cm}^{-1}$, these bands are assigned to the $v(\mathrm{OH})$ stretching vibration of the coordinated $\mathrm{H}_{2} \mathrm{O}$ molecules. The IR spectrum of lisinopril free ligand show strong absorption band at $1675 \mathrm{~cm}^{-1}$ due to $v(\mathrm{C}=\mathrm{O})$ stretching vibration of the carboxylic group [61]. The $\mathrm{Ca}(\mathrm{II}), \mathrm{Mg}(\mathrm{II}), \mathrm{Zn}(\mathrm{II}), \mathrm{Fe}(\mathrm{III})$ and $\mathrm{VO}(\mathrm{II})$ complexes show no absorption band at $1675 \mathrm{~cm}^{-1} v(\mathrm{C}=\mathrm{O})$, that is indicative of the deprotonation of $\mathrm{COOH}$ group and involvement of the carboxyl group in the formation of $\mathrm{M}-\mathrm{O}$ bonds [62]. The spectra of the complexes show two characteristic bands at (1404-1187), (1409-1187), (1400-1107),(1415-1155) and (1400-1105) $\mathrm{cm}^{-1}$ for $\mathrm{Ca}(\mathrm{II}), \mathrm{Mg}(\mathrm{II}), \mathrm{Zn}(\mathrm{II}), \mathrm{Fe}(\mathrm{III})$ and $\mathrm{VO}(\mathrm{II})$ complexes respectively, assigned as v(COO-) asymmetric and symmetric stretching vibrations of the ligated carboxylate anion respectively. The criteria that can be used to distinguish between the three binding states of the carboxylate complexes have been studied previously by Deacon and Phillips [63]. These criteria are: (a) $\Delta v>200 \mathrm{~cm}^{-1}$ (where $\left.\Delta v=\left[v_{\text {as }}(\mathrm{COO}-)-v_{\mathrm{s}}(\mathrm{COO}-)\right]\right)$ this relation was found in case of monodentate carboxylate complexes, (b) bidentate or chelating carboxylate complexes exhibit $\Delta v$ significantly smaller than ionic values $\left(\Delta v<100 \mathrm{~cm}^{-1}\right)$, and finally, (c) bridging complexes show $\Delta v$ comparable to ionic values $\left(\Delta v \sim 150 \mathrm{~cm}^{-1}\right)$. Therefore, the difference value $\Delta v$ is a useful characteristic for determining the coordination mode of the carboxylate group of the ligands. The observed $\Delta v$ for $\mathrm{Ca}(\mathrm{II}), \mathrm{Mg}(\mathrm{II}), \mathrm{Zn}$ (II), $\mathrm{Fe}(\mathrm{III})$ and $\mathrm{VO}(\mathrm{II})$ complexes (Table 2) fall in the range $217-295 \mathrm{~cm}^{-1}$ indicating a monodentate coordination mode of the carboxylate group $[64,65]$. The spectrum of lisinopril free ligand show absorption bands at 3100 and $3260 \mathrm{~cm}^{-1}$ due to $v(\mathrm{NH})$ stretching vibration of $-\mathrm{NH}$ and $-\mathrm{NH}_{2}$ groups respectively, these peaks are found in the spectra of the metal complexes with no significant change in their intensity and position. This observation suggests that both $-\mathrm{NH}$ and $\mathrm{NH}_{2}$ groups haven't involved in the coordination. The $v(\mathrm{~V}=\mathrm{O})$ stretching vibration in the vanadyl complex is observed as ex-

Table 2. IR frequencies $\left(\mathrm{cm}^{-1}\right)$ of lisinopril and its metal complexes.

\begin{tabular}{|c|c|c|c|c|c|c|c|c|c|}
\hline Compound & $\begin{array}{c}v(\mathrm{O}-\mathrm{H}) \\
\mathrm{H}_{2} \mathrm{O}\end{array}$ & $\begin{array}{c}v(\mathrm{NH}) ; \\
\mathrm{NH}_{2} \text { and } \mathrm{NH}\end{array}$ & $\begin{array}{l}v(\mathrm{C}=\mathrm{O}) \\
\mathrm{COOH}\end{array}$ & $\Delta\left(\mathrm{NH}_{2}\right)$ & $v_{\mathrm{as}}\left(\mathrm{COO}^{-}\right)$ & $v_{\mathrm{s}}\left(\mathrm{COO}^{-}\right)$ & $\Delta v$ & $v(\mathrm{M}-\mathrm{O})$ & $v(\mathrm{M}-\mathrm{N})$ \\
\hline lisinopril & - & $\begin{array}{l}3265 \\
3100\end{array}$ & 1675 & 1653 & - & - & - & - & - \\
\hline$\left[\mathrm{Ca}(\mathrm{Lis})(\mathrm{Cl})\left(\mathrm{NH}_{4}\right)\left(\mathrm{H}_{2} \mathrm{O}\right)_{4}\right] \cdot 2 \mathrm{H}_{2} \mathrm{O}$ & 3416 & $\begin{array}{l}3260 \\
3106\end{array}$ & - & 1632 & 1404 & 1187 & 217 & 551 & 490 \\
\hline$\left[\mathrm{Mg}(\mathrm{Lis})(\mathrm{Cl})\left(\mathrm{NH}_{4}\right)\left(\mathrm{H}_{2} \mathrm{O}\right)_{4}\right] \cdot 9 \mathrm{H}_{2} \mathrm{O}$ & 3407 & $\begin{array}{l}3250 \\
3099\end{array}$ & - & 1636 & 1409 & 1187 & 222 & 604 & 432 \\
\hline$\left[\mathrm{Zn}(\mathrm{Lis})\left(\mathrm{SO}_{4}\right)\left(\mathrm{NH}_{4}\right)\left(\mathrm{H}_{2} \mathrm{O}\right)_{3}\right] \cdot 9 \mathrm{H}_{2} \mathrm{O}$ & 3400 & $\begin{array}{l}3247 \\
3105\end{array}$ & - & 1608 & 1400 & 1107 & 293 & 615 & 428 \\
\hline$\left[\mathrm{Fe}(\mathrm{Lis})\left(\mathrm{NO}_{3}\right)_{2}\left(\mathrm{NH}_{4}\right)\left(\mathrm{H}_{2} \mathrm{O}\right)\right] \cdot \mathrm{H}_{2} \mathrm{O}$ & 3415 & $\begin{array}{l}3270 \\
3107\end{array}$ & - & 1632 & 1415 & 1155 & 260 & 550 & 463 \\
\hline$\left[\mathrm{VO}(\mathrm{Lis})\left(\mathrm{SO}_{4}\right)\left(\mathrm{NH}_{4}\right)_{2}\right] \cdot 4 \mathrm{H}_{2} \mathrm{O}$ & 3409 & $\begin{array}{l}3210 \\
3101\end{array}$ & - & 1618 & 1400 & 1105 & 295 & 615 & 490 \\
\hline
\end{tabular}


pected band at $960 \mathrm{~cm}^{-1}$, which is a good agreement with those known for many vanadyl complexes [66]. The coordination of nitrato group for the $\mathrm{Fe}$ (III) ions were also supported by check the IR spectrum of the ferric(III) complex, where the nitrato complex displayed two starching vibration bands at $1350 \mathrm{~cm}^{-1}$ and $1100 \mathrm{~cm}^{-1}$ assigned to $v_{\mathrm{as}}\left(\mathrm{NO}_{2}\right)$ and $v_{\mathrm{s}}\left(\mathrm{NO}_{2}\right)$ respectively, the stretching motion of $v(\mathrm{~N}=\mathrm{O})$ is observed at $1415 \mathrm{~cm}^{-1}$ as a very strong band, while the two bending motion of the type $\Delta\left(\mathrm{NO}_{2}\right)$ are well resolved and observed at 790 and $697 \mathrm{~cm}^{-1}$ suggesting that bidentate nitrato group [67,68]. Clearly the test against the presence of sulfate group in the $\mathrm{VO}$ (II) and $\mathrm{Zn}$ (II) complexes gave a positive result, this conclusion was supported by detected the two infrared frequencies bands at about 1100 and $600 \mathrm{~cm}^{-1}$ overlapping with angular deformation motions of the coordinated water molecules. New vibrating absorption bands were observed in the range of (550-615) $\mathrm{cm}^{-1}$ and (428490) $\mathrm{cm}^{-1}$ are assigned to the stretching absorption bands of M-O and M-N bands, respectively [69]. According to the IR data, the lisinopril coordinated to the metal ions as monodentate ligand via the carboxylate oxygen atom [30].

${ }^{1}$ H-NMR of lisinopril and its complexes: The ${ }^{1} \mathrm{H}-\mathrm{NMR}$ data of free lisinopril and its $\mathrm{Ca}$ (II) complex, as an example are listed in Table (3). Upon comparison the free lisinopril ligand with its metal complex $\mathrm{Ca}(\mathrm{II})$, the significant change is the disappearance of the characteristic peak for hydrogen of $-\mathrm{COOH}$ at $\Delta=$ $11.0 \mathrm{ppm}$ in $\mathrm{Ca}(\mathrm{II})$ complex indicates that the coordination of lisinopril ligand to $\mathrm{Ca}(\mathrm{II})$ through the deprotonated carboxylic group [70]. On other hand there is no significant change in the characteristic peaks of hydrogen for $-\mathrm{NH},-\mathrm{NH}_{2},-\mathrm{CH}_{2}$ and $-\mathrm{CH}$ groups of aromatic ring in the free lisinopril ligand and its $\mathrm{Ca}$ (II) complex. This discussion is supported that these groups are not involved in the complexation [70]. The appearance of new peaks at 3.65 and $3.76 \mathrm{ppm}$ in the spectra of $\mathrm{Ca}$ (II) complex which can assigned to the coordinated and uncoordinated of $\mathrm{H}_{2} \mathrm{O}$ molecules. In general, the structures of investigated complexes can be formulated as shown in Formulas (2-6).

Thermal analysis: The obtained lisinopril complexes were studied by thermogravimetric (TG), differential thermogravimetric (DTG) and (DTA) analysis from ambient temperature to $800{ }^{\circ} \mathrm{C}$ under nitrogen atmosphere. The TG curves were redrawn as mg mass loss versus temperature and DTG curves were redrawn as rate of loss of mass versus temperature. The thermal decomposition results are summarized in Table 4.

[Ca( $\left.\mathrm{Lis})(\mathrm{Cl})\left(\mathrm{NH}_{4}\right)\left(\mathrm{H}_{2} \mathrm{O}\right)_{4}\right] \cdot 2 \mathrm{H}_{2} \mathrm{O}$ complex: The thermal decomposition of $\mathrm{Ca}$ (II) complex of lisinopril with general formula $\left[\mathrm{Ca}(\mathrm{Lis})(\mathrm{Cl})\left(\mathrm{NH}_{4}\right)\left(\mathrm{H}_{2} \mathrm{O}\right)_{4}\right] \cdot 2 \mathrm{H}_{2} \mathrm{O}$ is occurs at four steps. The first degradation step is in the range of $23-174{ }^{\circ} \mathrm{C}$ at $\mathrm{DTG}_{\max }=61{ }^{\circ} \mathrm{C}$ and its assigned to the loss of $4\left(\mathrm{H}_{2} \mathrm{O}\right)$ mol-

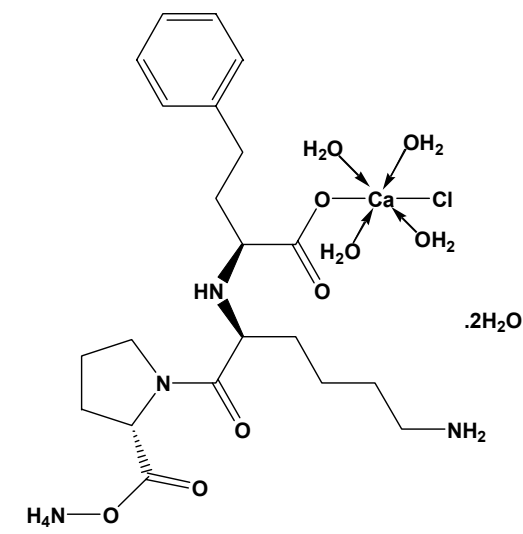

Formula 2. Suggested structures of $\mathrm{Ca}(\mathrm{II})$ complex of lisinopril.

ecules of hydration water with an observed weight loss $11.69 \%$ (calculated $=11.91 \%$ ), the activation energy of this step is 25.3 $\mathrm{kJmol}^{-1}$. The second step is occurred within a temperature range $174-342{ }^{\circ} \mathrm{C}$ at $\mathrm{DTG}_{\max }=296{ }^{\circ} \mathrm{C}$ due to the loss of $2\left(\mathrm{H}_{2} \mathrm{O}\right)$ molecules of coordinated water $+\mathrm{NH}_{4} \mathrm{Cl}+\mathrm{C}_{2} \mathrm{H}_{6}$ with a weight loss $($ Found $=20.57 \%$, Calculated $=19.77 \%)$, the activation energy of this step is $75.9 \mathrm{kJmol}^{-1}$. The third step is occurred within a temperature range $342-483{ }^{\circ} \mathrm{C}$ at $\mathrm{DTG}_{\max }=410{ }^{\circ} \mathrm{C}$ and DTA $=445{ }^{\circ} \mathrm{C}$ (exo) due to the loss $\mathrm{C}_{10} \mathrm{H}_{18} \mathrm{~N}_{2} \mathrm{O}_{2}$ (organic moiety) with an observed weight loss $33.07 \%$ (calculated $=$ $32.75 \%$ ), the activation energy of this step is $120 \mathrm{kJmol}^{-1}$. The fourth step is occurred within a temperature range $483-591{ }^{\circ} \mathrm{C}$ at $\mathrm{DTG}_{\max }=538{ }^{\circ} \mathrm{C}$ and DTA $=533{ }^{\circ} \mathrm{C}$ (exo) due to the loss of $\mathrm{C}_{3} \mathrm{H}_{5} \mathrm{NO}_{2}$ (organic moiety) with an observed weight loss $13.99 \%$ (Calculated $=14.39 \%)$, the activation energy of this step is $216 \mathrm{kJmol}^{-1}$. The $\mathrm{CaO}+$ residual carbon atoms are remaining stable till $800{ }^{\circ} \mathrm{C}$ as final residual.

[Mg(Lis) $\left.(\mathrm{Cl})\left(\mathrm{NH}_{4}\right)\left(\mathrm{H}_{2} \mathrm{O}\right)_{4}\right] \cdot 9 \mathrm{H}_{2} \mathrm{O}$ complex: The thermal decomposition of $\mathrm{Mg}$ (II) complex of lisinopril with general formula $\left[\mathrm{Mg}(\mathrm{Lis})(\mathrm{Cl})\left(\mathrm{NH}_{4}\right)\left(\mathrm{H}_{2} \mathrm{O}\right)_{4}\right] .9 \mathrm{H}_{2} \mathrm{O}$ is occurs at four steps. The first degradation step is in the range of $54-196{ }^{\circ} \mathrm{C}$ at $\mathrm{DTG}_{\max }=92{ }^{\circ} \mathrm{C}$ and its assigned to the loss of $5.5\left(\mathrm{H}_{2} \mathrm{O}\right) \mathrm{mol}-$ ecules of hydration water with an observed weight loss $14.13 \%$ (Calculated $=13.86 \%$ ), the activation energy of this step is $37.1 \mathrm{kJmol}^{-1}$. The second step is occurred within a temperature range $196-333{ }^{\circ} \mathrm{C}$ at $\mathrm{DTG}_{\max }=302{ }^{\circ} \mathrm{C}$ and DTA $=277^{\circ} \mathrm{C}$ (exo) assigned to the loss of $7.5\left(\mathrm{H}_{2} \mathrm{O}\right)$ molecules of hydration water with a weight loss (Found $=17.86 \%$, Calculated $=18.89 \%$ ), the activation energy of this step is $82.2 \mathrm{kJmol}^{-1}$. The third step is occurred within a temperature range $333-460{ }^{\circ} \mathrm{C}$ at $\mathrm{DTG}_{\max }=$ $399^{\circ} \mathrm{C}$ and DTA $=332^{\circ} \mathrm{C}$ (exo) assigned to the loss of $\mathrm{NH}_{4} \mathrm{Cl}+$ $\mathrm{C}_{7} \mathrm{H}_{13} \mathrm{~N}$ (organic moiety) with an observed weight loss $23.39 \%$

Table 3. ${ }^{1} \mathrm{H}-\mathrm{NMR}$ spectral data of lisinopril and its $\mathrm{Ca}(\mathrm{II})$ complex.

\begin{tabular}{lcccccc}
\hline \multicolumn{1}{c}{ Compound } & \multicolumn{5}{c}{$\delta$ ppm of hydrogen } \\
\hline Lisinopril & $\mathrm{H} ;-\mathrm{CH}_{2}$ & $\mathrm{H} ;-\mathrm{NH}_{2}$ & $\mathrm{H} ;-\mathrm{NH}-$ & $\mathrm{H} ;-\mathrm{CH}$ aromatic & $\mathrm{H} ;-\mathrm{OH}_{2}$ \\
$\mathrm{Ca}(\mathrm{II})$ complex & $1.55,1.97,2.20$ & 2.0 & 2.6 & $7.12,7.21$ & $-\mathrm{H} ;-\mathrm{COOH}$ \\
\hline
\end{tabular}




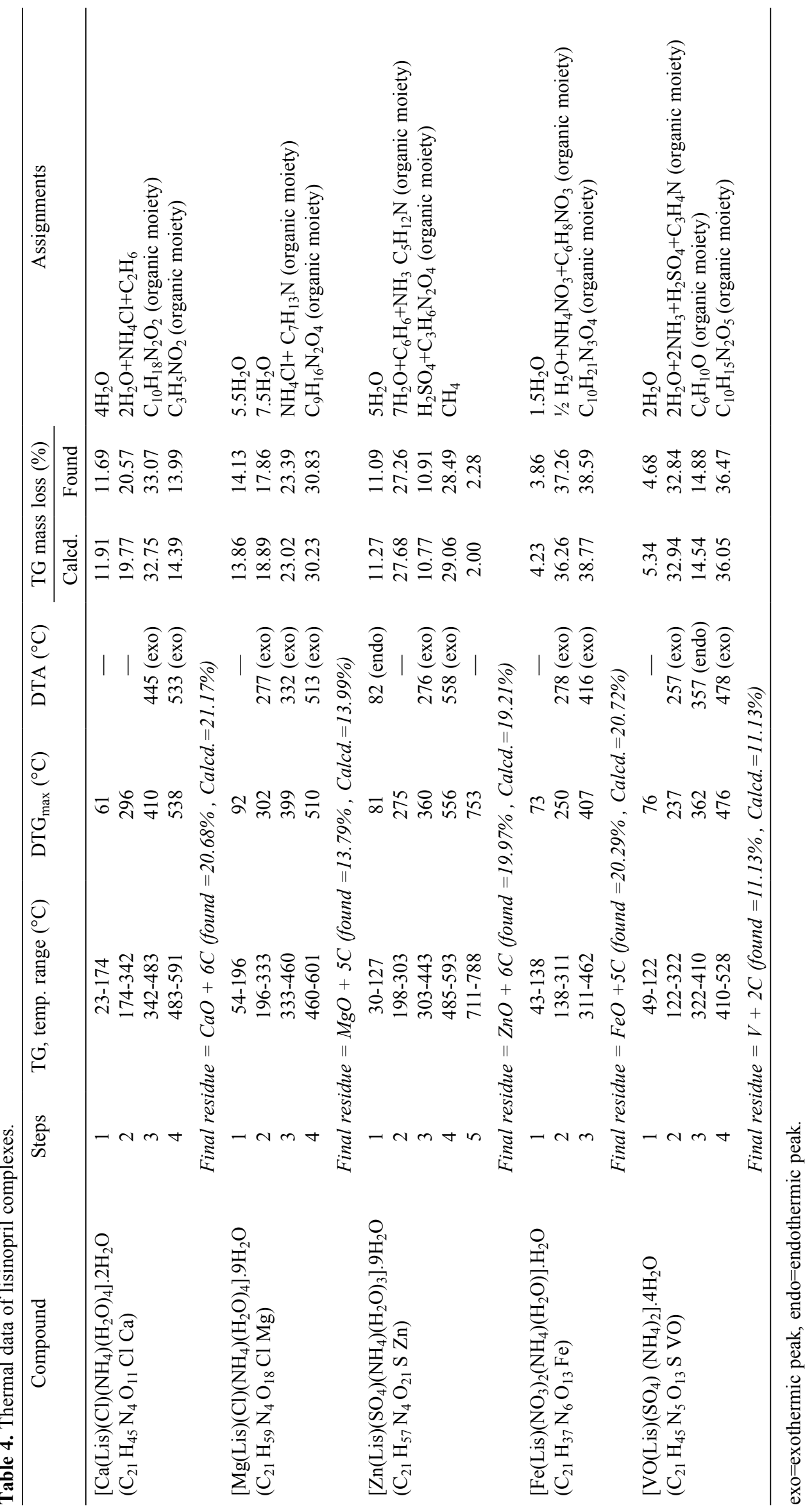




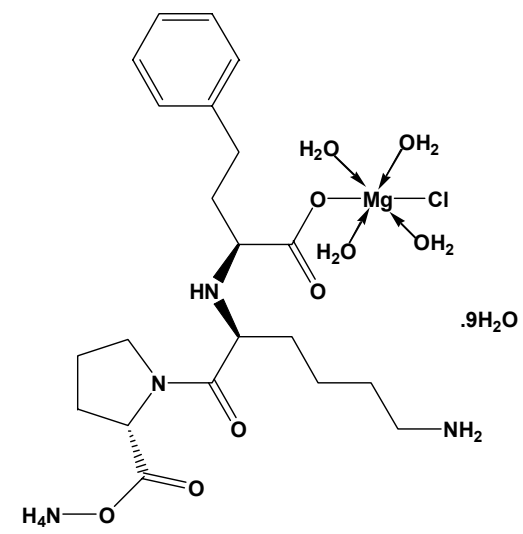

Formula 3. Suggested structures of $\mathrm{Mg}(\mathrm{II})$ complex of lisinopril.

(calculated $=23.02 \%$ ), the activation energy of this step is 108 $\mathrm{kJmol}^{-1}$. The fourth step is occurred within a temperature range $460-601{ }^{\circ} \mathrm{C}$ at $\mathrm{DTG}_{\max }=510^{\circ} \mathrm{C}$ and DTA $=513{ }^{\circ} \mathrm{C}$ (exo) due to the loss of $\mathrm{C}_{9} \mathrm{H}_{16} \mathrm{~N}_{2} \mathrm{O}_{4}$ (organic moiety) with an observed weight loss $30.83 \%$ (calculated $=30.23 \%$ ), the activation energy of this step is $188 \mathrm{kJmol}^{-1}$. The $\mathrm{MgO}$ residual carbon atoms are remaining stable till $800{ }^{\circ} \mathrm{C}$ as final residual.

[ Zn( $\left.\mathrm{Lis})\left(\mathrm{SO}_{4}\right)\left(\mathrm{NH}_{4}\right)\left(\mathrm{H}_{2} \mathrm{O}\right)_{3}\right] .9 \mathrm{H}_{2} \mathrm{O}$ complex: The thermal decomposition of $\mathrm{Zn}$ (II) complex of lisinopril with general formula $\left[\mathrm{Zn}(\mathrm{Lis})\left(\mathrm{SO}_{4}\right)\left(\mathrm{NH}_{4}\right)\left(\mathrm{H}_{2} \mathrm{O}\right)_{3}\right] \cdot 9 \mathrm{H}_{2} \mathrm{O}$ is occurs at five steps. The first degradation step is in the range of $30-127^{\circ} \mathrm{C}$ at $\mathrm{DTG}_{\max }=$ $81{ }^{\circ} \mathrm{C}$ and DTA $=82{ }^{\circ} \mathrm{C}$ (exo) and its assigned to the loss of $5\left(\mathrm{H}_{2} \mathrm{O}\right)$ molecules of hydration water with an observed weight loss $11.09 \%$ (Calculated $=11.27 \%$ ), the activation energy of this step is $55.3 \mathrm{kJmol}^{-1}$. The second step is occurred within a temperature range $198-303{ }^{\circ} \mathrm{C}$ at $\mathrm{DTG}_{\max }=275^{\circ} \mathrm{C}$ assigned to the loss of another $7\left(\mathrm{H}_{2} \mathrm{O}\right)$ molecules of hydration water $+\mathrm{C}_{6} \mathrm{H}_{6}$ $+\mathrm{NH}_{3}$ gas with a weight loss (Found $=27.26 \%$, Calculated $=$ $27.68 \%$ ), the activation energy of this step is $109 \mathrm{kJmol}^{-1}$. The third step is occurred within a temperature range $303-443{ }^{\circ} \mathrm{C}$ at $\mathrm{DTG}_{\max }=360{ }^{\circ} \mathrm{C}$ and DTA $=276^{\circ} \mathrm{C}$ (exo) assigned to the loss of $\mathrm{C}_{5} \mathrm{H}_{12} \mathrm{~N}$ (organic moiety) with observed weight loss $10.91 \%$ (calculated $=10.77 \%$ ), the activation energy of this step is 77.5 $\mathrm{kJmol}^{-1}$. The fourth step is occurred within a temperature range

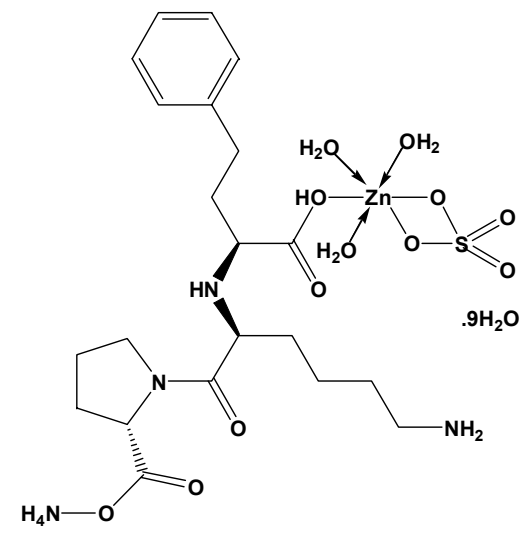

Formula 4. Suggested structures of $\mathrm{Zn}(\mathrm{II})$ complex of lisinopril.
485-593 ${ }^{\circ} \mathrm{C}$ at $\mathrm{DTG}_{\max }=556{ }^{\circ} \mathrm{C}$ and DTA $=558{ }^{\circ} \mathrm{C}$ (exo) assigned to the loss of $\mathrm{H}_{2} \mathrm{SO}_{4}+\mathrm{C}_{3} \mathrm{H}_{6} \mathrm{~N}_{2} \mathrm{O}_{4}$ (organic moiety) with an observed weight loss $28.49 \%$ (calculated $=29.06 \%$ ), the activation energy of this step is $296 \mathrm{kJmol}^{-1}$. The fifth step is occured within temperature range $711-788^{\circ} \mathrm{C}$ at $\mathrm{DTG}_{\max }=753$ ${ }^{\circ} \mathrm{C}$ assigned to the loss of $\mathrm{CH}_{4}$ with an observed weight loss $2.28 \%$ (calculated $=2.00 \%$ ). The $\mathrm{ZnO}+$ residual carbon atoms are remaining stable till $800{ }^{\circ} \mathrm{C}$ as final residual.

[Fe( $\left.\mathrm{Lis})\left(\mathrm{NO}_{3}\right)_{2}\left(\mathrm{NH}_{4}\right)\left(\mathrm{H}_{2} \mathrm{O}\right)\right] \cdot \mathrm{H}_{2} \mathrm{O}$ complex: The thermal decomposition of $\mathrm{Fe}$ (III) complex of lisinopril with general formula $\left[\mathrm{Fe}(\mathrm{Lis})\left(\mathrm{NO}_{3}\right)_{2}\left(\mathrm{NH}_{4}\right)\left(\mathrm{H}_{2} \mathrm{O}\right)\right] \cdot \mathrm{H}_{2} \mathrm{O}$ is occurs at three steps. The first degradation step is in the range of $43-138{ }^{\circ} \mathrm{C}$ at $\mathrm{DTG}_{\max }=73{ }^{\circ} \mathrm{C}$ and its assigned to the loss of $1.5\left(\mathrm{H}_{2} \mathrm{O}\right) \mathrm{mol}-$ ecules of hydration water with an observed weight loss $3.86 \%$ (Calculated $=4.23 \%$ ), the activation energy of this step is 49.9 $\mathrm{kJ} \mathrm{mol}^{-1}$. The second step is occurred within a temperature range $138-311^{\circ} \mathrm{C}$ at $\mathrm{DTG}_{\max }=250{ }^{\circ} \mathrm{C}$ and $\mathrm{DTA}=278{ }^{\circ} \mathrm{C}$ (exo) assigned to the loss of $1 / 2\left(\mathrm{H}_{2} \mathrm{O}\right)$ molecules of hydration water $+\mathrm{NH}_{4} \mathrm{NO}_{3}+\mathrm{C}_{6} \mathrm{H}_{8} \mathrm{NO}_{3}$ (organic moiety) with observed weight loss $37.26 \%$ (calculated $=36.26 \%$ ), the activation energy of this step is $69.1 \mathrm{~kJ} \mathrm{~mol}^{-1}$. The third step is occurred within a temperature range $311-462{ }^{\circ} \mathrm{C}$ at $\mathrm{DTG}_{\max }=407{ }^{\circ} \mathrm{C}$ and DTA $=416{ }^{\circ} \mathrm{C}$ (exo) assigned to the loss of $\mathrm{C}_{10} \mathrm{H}_{21} \mathrm{~N}_{3} \mathrm{O}_{4}$ (organic moiety) with observed weight loss $38.59 \%$ (Calculated $=38.77 \%$ ), the activation energy of this step is $111 \mathrm{~kJ} \mathrm{~mol}^{-1}$. The $\mathrm{FeO}$ residual carbon atoms are remaining stable till 800 ${ }^{\circ} \mathrm{C}$ as final residual.

[VO(Lis) $\left(\mathrm{SO}_{4}\right)\left(\mathrm{NH}_{4}\right)_{2}$ ].4H $\mathrm{H}_{2} \mathrm{O}$ complex: The thermal decomposition of $\mathrm{VO}$ (II) complex of lisinopril with general formula [VO(Lis) $\left.\left(\mathrm{SO}_{4}\right)\left(\mathrm{NH}_{4}\right)_{2}\right] \cdot 4 \mathrm{H}_{2} \mathrm{O}$ is occurs at four steps. The first degradation step is in the range of $49-122^{\circ} \mathrm{C}$ at $\mathrm{DTG}_{\max }=76^{\circ} \mathrm{C}$ and it is assigned to the loss of $2\left(\mathrm{H}_{2} \mathrm{O}\right)$ molecules of hydration water with an observed weight loss $4.68 \%$ (calcd. $=5.34 \%$ ), the activation energy of this step is $62.5 \mathrm{~kJ} \mathrm{~mol}^{-1}$. The second step is occurred within a temperature range $122-322{ }^{\circ} \mathrm{C}$ at $\mathrm{DTG}_{\max }$ $=237{ }^{\circ} \mathrm{C}$ and DTA $=257{ }^{\circ} \mathrm{C}$ (exo) assigned to the loss of another $2\left(\mathrm{H}_{2} \mathrm{O}\right)$ molecules of hydration $+2 \mathrm{NH}_{3}$ gas $+\mathrm{H}_{2} \mathrm{SO}_{4}$ $+\mathrm{C}_{3} \mathrm{H}_{4} \mathrm{~N}$ (organic moiety) with observed weight loss $32.84 \%$ (Calculated $=32.94 \%$ ), the activation energy of this step is 39.6 $\mathrm{kJ} \mathrm{mol}^{-1}$. The third step is occurred within a temperature range

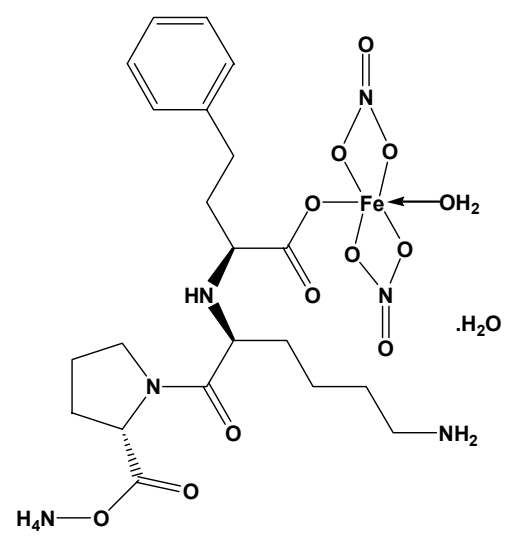

Formula 5. Suggested structures of Fe(III) complex of lisinopril. 


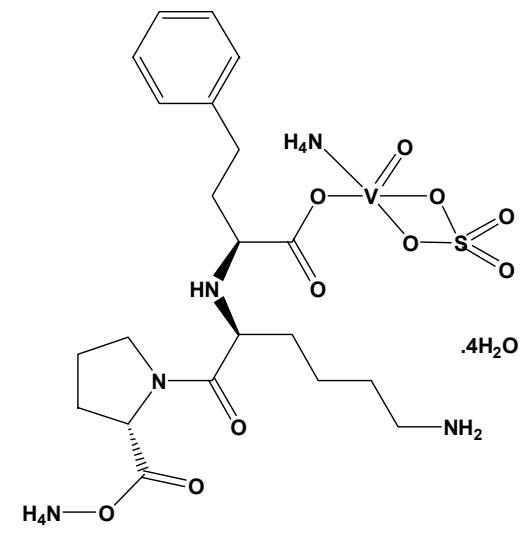

Formula 6. Suggested structures of VO(II) complex of lisinopril.

$322-410{ }^{\circ} \mathrm{C}$ at $\mathrm{DTG}_{\max }=362{ }^{\circ} \mathrm{C}$ and DTA $=357{ }^{\circ} \mathrm{C}$ (endo) assigned to the loss of $\mathrm{C}_{6} \mathrm{H}_{10} \mathrm{O}$ (organic moiety) with observed weight loss $14.88 \%$ (Calculated $=14.54 \%$ ), the activation energy of this step is $130 \mathrm{~kJ} \mathrm{~mol}^{-1}$. The fourth step is occurred within a temperature range $410-528{ }^{\circ} \mathrm{C}$ at $\mathrm{DTG}_{\max }=476{ }^{\circ} \mathrm{C}$ and DTA $=478{ }^{\circ} \mathrm{C}$ (exo) assigned to the loss of $\mathrm{C}_{10} \mathrm{H}_{15} \mathrm{~N}_{2} \mathrm{O}_{5}$ (organic moiety) with observed weight loss $36.47 \%$ (Calculated $=36.05 \%$ ), the activation energy of this step is $219 \mathrm{~kJ} \mathrm{~mol}^{-1}$. The $\mathrm{V}+$ residual carbon atoms are remaining stable till $800{ }^{\circ} \mathrm{C}$ as final residual.

Kinetic studies: In the present investigation, the general thermal behaviors of the lisinopril complexes in terms of stability ranges, maximum temperature peaks and values of kinetic parameters, are shown in Table (5). The kinetic and thermodynamic parameters are evaluated using the Coats-Redfern and Horowitz-Metzger equations [71-73]. The entropy of activation, $\Delta \mathrm{S}^{*}$, is calculated. The enthalpy activation, $\Delta \mathrm{H}^{*}$, and Gibbs free energy, $\Delta \mathrm{G}^{*}$, are calculated from $\Delta \mathrm{H}^{*}=\mathrm{E}^{*}-\mathrm{RT}$ and $\Delta \mathrm{G}^{*}=\Delta \mathrm{H}^{*}-\mathrm{T} \Delta \mathrm{S}^{*}$, respectively. The thermodynamic behavior of most lisinopril complexes with $\mathrm{Ca}$ (II), $\mathrm{Mg}$ (II), $\mathrm{Zn}$ (II), $\mathrm{Fe}$ (III) and $\mathrm{VO}(\mathrm{II})$ metal ions is non-spontaneous (more ordered) reactions $(\Delta \mathrm{S}$ is negative value), endothermic reactions $(\Delta \mathrm{H}>0)$ and endergonic $(\Delta \mathrm{G}>0)$, during the reactions. The thermodynamic data obtained with the two methods are in harmony with each other. The correlation coefficients of the Arrhenius plots of the thermal decomposition steps were found to lie in the range 0.9637-0.9996, showing a good fit with linear function. The thermograms and the calculated thermal parameters for the complexes show that the stability of these complexes depends on the nature of the central metal ion. The thermal stability of the metal complexes was found to increase periodically with increase in atomic number of the metal and the larger value of charge/radius ratio [74].

Microbiological investigation of lisinopril complexes: Antibacterial and antifungal activities of lisinopril complexes were carried out against of bacteria as Escherichia coli (Gram -ve) and Staph albus (Gram +ve) as well as fungi as Aspergillus niger and Aspergillus flavus. The antimicrobial activities based on the size of inhibition zone around dishes were estimated. The free lisinopril has the lowest activity against four types of bacteria and fungi, while the $\mathrm{Zn}$ (II) complex was found to have the highest activity. The biological activities increase in the following order: $\mathrm{Zn}(\mathrm{II}) / \mathrm{Lis}>\mathrm{VO}(\mathrm{II}) / \mathrm{Lis}>\mathrm{Fe}(\mathrm{III}) / \mathrm{Lis}>\mathrm{Ca}(\mathrm{II}) / \mathrm{Lis}$ $>\mathrm{Mg}(\mathrm{II}) / \mathrm{Lis}$. The data are listed in Table 6.

\section{Experimental part}

Materials: All chemicals used in this investigation were of highest purity grade (Merck). Selected metal salts as $\mathrm{CaCl}_{2}$, $\mathrm{MgCl}_{2} \cdot 6 \mathrm{H}_{2} \mathrm{O}, \mathrm{ZnSO}_{4} \cdot \mathrm{H}_{2} \mathrm{O}, \mathrm{Fe}\left(\mathrm{NO}_{3}\right)_{3} \cdot 9 \mathrm{H}_{2} \mathrm{O}$ and $\mathrm{VOSO}_{4} \cdot \mathrm{H}_{2} \mathrm{O}$ were used. Lisinopril were received from Egyptian International Pharmaceutical Industrial Company.

Preparation of solid lisinopril complexes: $\left[\mathrm{Ca}(\mathrm{Lis})(\mathrm{Cl})\left(\mathrm{NH}_{4}\right)\right.$ $\left.\left(\mathrm{H}_{2} \mathrm{O}\right)_{4}\right] \cdot 2 \mathrm{H}_{2} \mathrm{O}(\mathrm{I}),\left[\mathrm{Mg}(\mathrm{Lis})(\mathrm{Cl})\left(\mathrm{NH}_{4}\right)\left(\mathrm{H}_{2} \mathrm{O}\right)_{4}\right] \cdot 9 \mathrm{H}_{2} \mathrm{O}(\mathrm{II}),[\mathrm{Zn}($ Lis) $\left.\left(\mathrm{SO}_{4}\right)\left(\mathrm{NH}_{4}\right)\left(\mathrm{H}_{2} \mathrm{O}\right)_{3}\right] .9 \mathrm{H}_{2} \mathrm{O}(\mathrm{III}),\left[\mathrm{Fe}(\mathrm{Lis})\left(\mathrm{NO}_{3}\right)_{2}\left(\mathrm{NH}_{4}\right)\left(\mathrm{H}_{2}\right.\right.$ $\mathrm{O})] . \mathrm{H}_{2} \mathrm{O}(\mathrm{IV})$ and $\left[\mathrm{VO}(\mathrm{Lis})\left(\mathrm{SO}_{4}\right)\left(\mathrm{NH}_{4}\right)_{2}\right] \cdot 4 \mathrm{H}_{2} \mathrm{O}(\mathrm{V})$ were prepared, employing a 1:1 (metal:Lis) ratio. The complexes were prepared by mixing equal volumes $(20 \mathrm{~mL})$ of distilled water solution of $\mathrm{CaCl}_{2}(0.111 \mathrm{~g}, 1.0 \mathrm{mmol}), \mathrm{MgCl}_{2} \cdot 6 \mathrm{H}_{2} \mathrm{O}(0.203 \mathrm{~g}$, $1.0 \mathrm{mmol}), \mathrm{ZnSO}_{4} \cdot \mathrm{H}_{2} \mathrm{O}(0.180 \mathrm{~g}, 1.0 \mathrm{mmol}), \mathrm{Fe}\left(\mathrm{NO}_{3}\right)_{3} .9 \mathrm{H}_{2} \mathrm{O}$ $(0.404 \mathrm{~g}, 1.0 \mathrm{mmol})$ and $\mathrm{VOSO}_{4} \cdot \mathrm{H}_{2} \mathrm{O}(0.163 \mathrm{~g}, 1.0 \mathrm{mmol})$ with a methanol solution of lisinopril $(0.405 \mathrm{~g}, 1.0 \mathrm{mmol})$. The mixtures are neutralized at $\mathrm{pH}(7.0-9.0)$ using 5\% alcoholic ammonia solution, then the mixtures are heating at about $\sim 60$ ${ }^{\circ} \mathrm{C}$ for about one hour with stirring and left to evaporate slowly at room temperature overnight. The obtained precipitates were filtered off, washed several times by minimum amount of hot methanol and dried at $60{ }^{\circ} \mathrm{C}$ over anhydrous $\mathrm{CaCl}_{2}$. The melting points of the five lisinopril complexes are observed within the range of $226-266^{\circ} \mathrm{C}$. The $\mathrm{Ca}(\mathrm{II}), \mathrm{Mg}(\mathrm{II}), \mathrm{Zn}(\mathrm{II}), \mathrm{Fe}(\mathrm{II})$ and VO(II) complexes are soluble in dimethyl sulfoxide (DMSO) and $\mathrm{N}, \mathrm{N}$-dimethylformamide $(D M F)$ with gently heating. The yield of lisinopril complexes is in the range of $60-75 \%$.

Preparations of stock: Ten $\mathrm{g}$ of barium chloride dihydrate $\mathrm{BaCl}_{2} \cdot 2 \mathrm{H}_{2} \mathrm{O}$ is weighted and dissolved in the least amount of distilled water. The volume was completed to $100 \mathrm{~mL}$ in a measuring flask to give $10 \%$ solution.

A weight of $0.1701 \mathrm{~g}$ of $\mathrm{AgNO}_{3}$ was dissolved in $100 \mathrm{~mL}$ distilled water in a dark measuring flask to obtain an approximate $0.01 \mathrm{M}$ solution.

The stock solution of $\mathrm{NH}_{4} \mathrm{OH}$ was prepared by taking $15.15 \mathrm{~mL}$ of the concentrate $\mathrm{NH}_{3}(33 \% \mathrm{v} / \mathrm{v})$ in $35 \mathrm{~mL}$ distilled water. The volume was then completed to $100 \mathrm{~mL}$ by methanol to give approximately $(5 \% \mathrm{v} / \mathrm{v})$ solution.

A weight of $0.2 \mathrm{~g}$ of the solid lisinopril complex was dissolved in the least amount of $2 \mathrm{~mol}$ nitric acid. The solution was evaporated near dryness. This process is repeated twice and the residue was dissolved in about $50 \mathrm{~mL}$ of hot distilled water to obtain a clear solution. The volume was completed to $100 \mathrm{~mL}$ in a measuring flask.

Apparatus and experimental conditions: Carbon, hydrogen and nitrogen content were determined using a Perkin-Elmer CHN Elemental Analyzer model 2400. The metal content was found gravimetrically by converting the compounds into their corresponding carbides or oxides. The $\mathrm{Ca}(\mathrm{II}), \mathrm{Mg}(\mathrm{II}), \mathrm{Zn}(\mathrm{II})$, 
Table 5. Thermodynamic parameters of the lisinopril complexes.

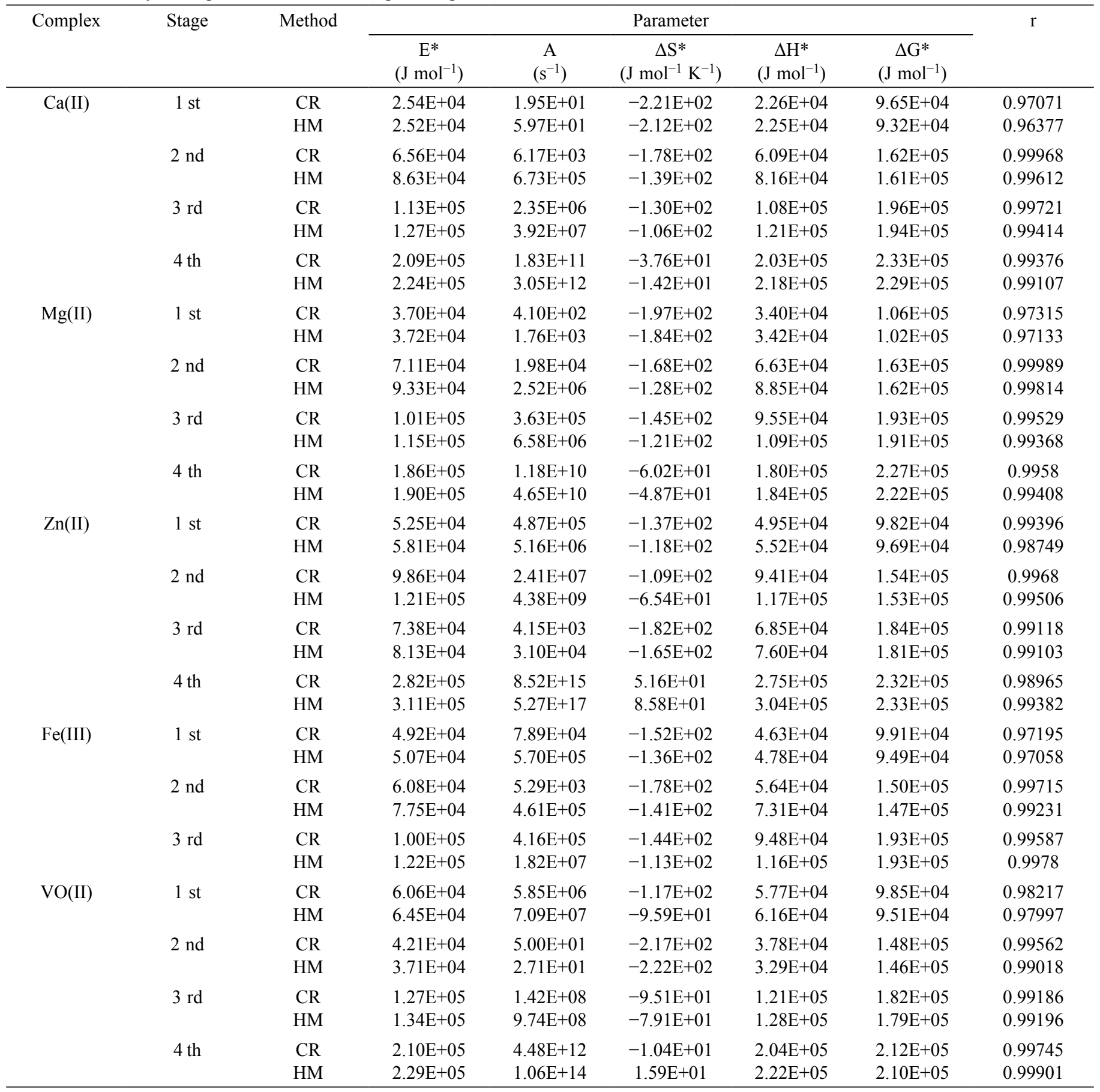

$\Delta \mathrm{S}^{*}$ : entropy of activation, $\Delta \mathrm{H}^{*}$ : enthalpy of activation, $\Delta \mathrm{G}^{*}$ : Gibbs free energy, $\mathrm{E}^{*}$ : activation energy, A: pre-exponential factor and $\mathrm{r}=$ correlation coefficient of the linear plot.

(CR): Coats and Redfern and (HM): Horowitz-Metzger equations.

$\mathrm{Fe}(\mathrm{III})$ and $\mathrm{VO}(\mathrm{II})$ contents were determined gravimetrically by the direct ignition of the complexes at $800{ }^{\circ} \mathrm{C}$ for 3 hours till constant weight. The residue was then weighted in the forms of metal oxides. Molar conductivities of freshly prepared $1.0 \times$ $10^{-3}$ mol DMSO solutions of the complexes were measured using Jenway 4010 conductivity meter. IR spectra were recorded on Bruker FTIR Spectrophotometer (4000-400 $\mathrm{cm}^{-1}$ ) in $\mathrm{KBr}$ pellets. The electronic spectra were measured in the DMSO solvent with concentration $\left(1.0 \times 10^{-3} \mathrm{M}\right)$ for the free ligands and their complexes using Jenway 6405 spectrophotometer with 1 $\mathrm{cm}$ quartz cell, in the range $200-900 \mathrm{~nm}$. ${ }^{1} \mathrm{H}-\mathrm{NMR}$ spectra of the free ligands and their complexes were recorded on Varian Gemini 200 MHZ Spectrophotometer using DMSO-d $\mathrm{d}_{6}$ as solvent and TMS as internal reference. Thermogravimetric analy- 
Table 6. Antimicrobial data of lisinopril and its complexes.

\begin{tabular}{lcccc}
\hline \multicolumn{1}{c}{ Compound } & \multicolumn{5}{c}{ Diameter of inhibition zone $(\mathrm{cm})$} \\
\hline Control & E. coli & Staph albus & Aspergillus niger & Aspergillus flavus \\
lisinopril & 0 & 0 & 0 & 0 \\
$\mathrm{Ca}(\mathrm{II}) /$ Lis complex & 0 & 0 & 0 & 0 \\
$\mathrm{Mg}(\mathrm{II}) /$ Lis complex & 0 & 0 & 0 & 0.4 \\
$\mathrm{Zn}(\mathrm{II}) /$ Lis complex & 0 & 0 & 0 & 0.3 \\
$\mathrm{Fe}(\mathrm{III}) /$ Lis complex & 0 & 0.2 & 0.3 & 0.5 \\
$\mathrm{Vo}(\mathrm{II}) /$ Lis complex & 0 & 0 & 0 & 0.5 \\
\hline
\end{tabular}

sis (TGA, DTG and DTA) was carried out in the temperature range from 25 to $800{ }^{\circ} \mathrm{C}$ in a steam of nitrogen atmosphere by using Shimadzu TGA-50 H thermal analyzer. The experimental conditions were: platinum crucible, nitrogen atmosphere with a $30 \mathrm{~mL} / \mathrm{min}$ flow rate and a heating rate of $10^{\circ} \mathrm{C} / \mathrm{min}$.

Most commonly used methods are the differential method of Freeman and Carroll [71] integral method of Coat and Redfern [72] and the approximation method of Horowitz and Metzger [73]. In the present investigation, the general thermal behaviors of the lisinopril complexes in terms of stability ranges, peak temperatures and values of kinetic parameters are discussed. The kinetic parameters have been evaluated using the Coats-Redfern equation:

$$
\int_{0}^{\alpha} \frac{d \alpha}{(1-\alpha)^{n}}=\frac{A}{\phi} \int_{T_{1}}^{T_{2}} \exp \left(-\frac{E^{*}}{R T}\right) d t
$$

This equation on integration gives;

$$
\ln \left[-\frac{\ln (1-\alpha)}{T^{2}}\right]=-\frac{E^{*}}{R T}+\ln \left[\frac{A R}{\phi E^{*}}\right]
$$

Where $\varphi$ is the linear heating rate, $R$ is the gas constant, $\mathrm{T}$ is the DTG temperature peak, $\alpha$, is the fraction of the sample decomposed at time $\mathrm{t}, \mathrm{A}$ is the pre-exponential factor. A plot of left-hand side against $1 / T$ was drawn. $E^{*}$ is the energy of activation in $\mathrm{J} \mathrm{mol}^{-1}$ and calculated from the slop and $\mathrm{A}$ in $\left(\mathrm{s}^{-1}\right)$ from the intercept value. The entropy of activation $\Delta \mathrm{S}^{*}$ in $\left(\mathrm{JK}^{-1} \mathrm{~mol}^{-1}\right)$ was calculated by using the equation:

$$
\Delta \mathrm{S}^{*}=\mathrm{R} \ln \left(\mathrm{Ah} / \mathrm{k}_{\mathrm{B}} \mathrm{T}_{\mathrm{s}}\right)
$$

Where $\mathrm{k}_{\mathrm{B}}$ is the Boltzmann constant, $\mathrm{h}$ is the Plank's constant and $\mathrm{T}_{\mathrm{s}}$ is the DTG peak temperature [75].

The Horowitz-Metzger equation is an illustrative of the approximation methods.

$\log \left[\left\{1-(1-\alpha)^{1-\mathrm{n}}\right\} /(1-n)\right]=\mathrm{E}^{*} \theta / 2.303 \mathrm{RT}_{\mathrm{s}}^{2}$ for $n \neq 1$

When $n=1$, the LHS of equation 4 would be $\log [-\log (1$ $-\alpha)$ ]. For a first-order kinetic process the Horowitz-Metzger equation may be written in the form:

$$
\log \left[\log \left(\mathrm{w}_{\alpha} / \mathrm{w}_{\gamma}\right)\right]=\mathrm{E}^{*} \theta / 2.303 \mathrm{RT}_{\mathrm{s}}^{2}-\log 2.303
$$

Where $\theta=\mathrm{T}-\mathrm{T}_{\mathrm{s}}, \mathrm{w}_{\gamma}=\mathrm{w}_{\alpha}-\mathrm{w}, \mathrm{w}_{\alpha}=$ mass loss at the completion of the reaction. The plot of $\log \left[\log \left(\mathrm{w}_{\alpha} / \mathrm{w}_{\gamma}\right)\right]$ vs $\theta$ was drawn and found to be linear from the slope of which $\mathrm{E}^{*}$ was calculated. The pre-exponential factor, A, was calculated from the equation:

$$
\mathrm{E}^{*} / \mathrm{RT}_{\mathrm{s}}^{2}=\mathrm{A} /\left[\varphi \exp \left(-\mathrm{E}^{*} / \mathrm{RT}_{\mathrm{s}}\right)\right]
$$

The entropy of activation, $\Delta \mathrm{S}^{*}$, was calculated from equation 3. The enthalpy activation, $\Delta \mathrm{H}^{*}$, and Gibbs free energy, $\Delta \mathrm{G}^{*}$, were calculated from; $\Delta \mathrm{H}^{*}=\mathrm{E}^{*}-\mathrm{RT}$ and $\Delta \mathrm{G}^{*}=\Delta \mathrm{H}^{*}$ - T $\Delta \mathrm{S}^{*}$, respectively.

Microbiological investigation: According to Gupta et al. [76], the hole well method was applied. The investigated isolates of bacteria and fungi were seeded in tubes with nutrient broth (NB) and Dox's broth (DB), respectively. The seeded (NB) for bacteria and (DB) for fungi $(1 \mathrm{~mL})$ were homogenized in the tubes with $9 \mathrm{~mL}$ of melted $\left(45^{\circ} \mathrm{C}\right)$ nutrient agar (NA) for bacteria and (DA) for fungi. The homogenous suspensions were poured into Petri dishes. The holes (diameter $0.5 \mathrm{~cm}$ ) were done in the cool medium. A $100 \mu \mathrm{L}$ of the investigated compounds were taken using a micropipette. After incubation for $24 \mathrm{~h}$ in an incubator at $37^{\circ} \mathrm{C}$ and $28^{\circ} \mathrm{C}$ for bacteria and fungi, respectively, the inhibition zone diameter were measured and expressed in $\mathrm{cm}$. The antimicrobial activities of the investigated compounds were tested against of bacteria as Escherichia coli $(\mathrm{Gram}-\mathrm{ve})$ and Staph albus (Gram $+\mathrm{ve})$ as well as fungi as Aspergillus flavus and Aspergillus niger. At the same time the pure solvent was tested with the antimicrobial investigations of the complexes. The concentration of each solution was 1.0 $\times 10^{-3} \mathrm{~mol} / \mathrm{L}$. Commercial DMSO was employed to dissolve the tested samples.

\section{References}

1. Sekhon, B.S. J. Pharm. Educ. Res. 2011, 2(1), 1-20.

2. Xiao, D.R.; Wang, E.B.; An, H.Y.; Su, Z.M.; Li, Y.G.; Gao, L.; Sun, C.Y.; Xu, L. Chem. Eur. J. 2005, 11, 6673-6686.

3. Drevensek, P.; Zupancic, T.; Pihlar, B.; Jerala, R.; Kolitsch, U.; Plaper, A.; Turel, I. J. Inorg. Biochem. 2005, 99, 432-442.

4. He, J.H.; Xiao, D.R.; Chen, H.Y.; Yan, S.W.; Sun, D.Z.; Wang, X.; Yang, J.; Yuan, R.; Wang, E.B. Inorg. Chim. Acta 2012, 385, 170-177. 
5. Laxmi, K.; Sproules, S.; Pawar, O.; Markad, G.; Haram, S.; Puranik, V.; Salunke-Gawali, S. J. Mol. Struct. 2013, 1048, 223-229.

6. Gielen, M.; Tiekink, E.R.T., Eds., Metallotherapeutic Drugs and Metal-Based Diagnostic Agents, the Use of Metals in Medicine, Wiley, Chichester, 2005.

7. Bharti, S.K.; Singh, S.K. Pharmacia Lett. 2009, 1(2), 39-51.

8. Weder, J.E.; Dillon, C.T.; Hambley, T.W.; Kennedy, B.J.; Lay, P.A.; Biffin, J.R.; Regtop, H.L.; Daview, N.M. Coord. Chem. Rev. 2002, 232, 95-126.

9. Ware, D.C.; Brothers, P.J.; Clark, G.R. J. Chem. Soc. Dalton Trans. 2000, 925-932.

10. Nakai, M.; Sekiguchi, F.; Obata, M.; Ohtsuki, C.; Adachi, Y.; Sakurai, H.; Orvig, C.; Rehder, D.; Yano, S. J. Inorg. Biochem. 2005, 99, 1275-1282.

11. Chaviara, T.; Christidis, P.C.; Papageorgiou, A.; Chrysogelou, E.; Hadjipavlou-Litina, D.J.; Bolos, C.A. J. Inorg. Biochem. 2005, 99, 2102-2109.

12. Sadler, P.J.; Guo, Z. Pure Appl. Chem. 1998, 70, 863-871.

13. Baslas, R.K.; Zamani, R.; Nomani, A.A. Experientia 1979, 35, 455-456.

14. Gonzalez, B.E.; Daeid, N.N.; Nolan, K.B.; Farkas, E. Polyhedron 1994, 13, 1495-1499.

15. Nolan, K.B.; Soudi, AA. Inorg. Chim. Acta 1995, 230, 209-210.

16. Muller, J.G.; Burrows, C.J. Inorg. Chim. Acta, 1998, 275, 314-319.

17. Underhill, A.E.; Bougourd, S.A.; Flugge, M.L.; Gale, S.E.; Gomm, P.S. J. Inorg. Biochem. 1993, 52, 139-144.

18. Lawal, A.; Obaleye, J.A. Biokemistri 2007, 19(1), 9-15.

19. Kirkova, M.; Atanassova, M.; Russanov, E. Gen. Pharmacol. 1999, 33, 271-276.

20. Duda, A.M.; Kowalik-Jankowska, T.; Kozlowski, H.; Kupka, T.,J. Chem. Soc. Dalton Trans 1995, 2909-2913.

21. Kubiak, M.; Duda, A.M.; Ganadu, M.L.; Kozlowski, H. J. Chem. Soc. Dalton Trans 1996, 1905-1908.

22. Umadevi, B.; Muthiah, P.T.; Shui, X.; Eggleston, D.S. Inorg. Chim. Acta 1995, 234, 149-152.

23. Sanchez-del Grado, R.A.; Navarro, M.; Perez, H.; Urbina, J.A. J. Med. Chem. 1996, 39, 1095-1099.

24. Behrens, N.B.; Diaz, G.M.; Goodgame, D.M.L. Inorg. Chim. Acta 1986, 125, 21-264.

25. Xie, Y.-M.; Wu, J.-H. Inorg. Chim. Acta 2014, 412, 15-19

26. Cao, X.; Yu, L.; Huang, R. J. Solid State Chem. 2014, 210(1), 74-78.

27. Sutrisno, A.; Huang, Y. Solid State Nuclear Magnetic Resonance 2013, 49-50, 1-11.

28. Zheng, X.-P.; Lu, Y.; Zhang, H.; Zhang, Z.-m.; Wang, E.-b. Inorg. Chem. Commun. 2013, 33, 29-32

29. Lpez-Gresa, M.P.; Ortiz, R.; Perell, L.; Latorre, J.; Liu-Gonzalez, M.; Garcia- Granda, M.; Pe rez-Priede, M.; Cantn, E.; J. Inorg. Biochem. 2002, 92, 65.

30. Turel, I. Coord. Chem. Rev. 2002, 232, 27-47.

31. Xiao, D.R.; Wang, E.B.; An, H.Y.; Li, Y.G.; Xu, L. Cryst. Growth Des. 2007, 7, 506-512.

32. Xiao, D.R.; He, J.H.; Sun, D.Z.; Chen, H.Y.; Yan, S.W.; Wang, X.; Yang, J.; Yuan, R.; Wang, E.B. Eur. J. Inorg. Chem. 2012, 1783-1789.

33. Palumbo, M.; Gatto, B.; Zagotto, G.; Palu, G. Trends. Microbiol. 1993, 1, 232-235.

34. Sissi, C.; Andreolli, M.; Cecchetti, V.; Fravolini, A.; Gatto, B.; Palumbo, M. Bioorg. Med. Chem. 1998, 6, 1555-1561.

35. Lancaster, S.G.; Todd, P.A. Drugs 1988, 35, 646-669.

36. Rush, J.E.; Merrill, D.D. J. Cardiovasc. Pharm. 1987, 9, 99-107.

37. Gomez, H.J.; Smith, S.G.; Moncloa, F. Am. J. Med. 1988, 85, 35-37.

38. Beermann, B.; Till, A.E.; Gomez, H.J.; Hichens, M.; Bolognese, J.A.; Junggren, I.L. Biopharm. Drug Disposit. 1989, 10, 397-409.

39. The United States Pharmacopeia, $24^{\text {th }}$ Revision, the National Formulary, $19^{\text {th }}$ Revision, United States Pharmacopeial Convention, Inc., Rockville, MD, 2000.
40. El-Gindy, A.; Ashour, A.; Abdel-Fattah, L. J. Pharm. Biomed. Anal. 2001, 25, 913-922.

41. Qin, X.Z.; Nguyen, D.S.T.; Ip, D.P. J. Liq. Chromatogr. 1993, 16(17), 3713.

42. Kalal, H.S.; Rafiei, J.; Bani, F. Int. J. Environ. Res. 2010, 4, 289296.

43. Du, J.; Ji, X.J.; Huang, H. Chin. J. Anal. Chem. 2009, 37, 681684.

44. El-Yazbi, F.A.; Abdine, H.H.; Shaalan, R.A. J. Pharm. Biomed. Anal. 1999, 19(6), 819-827.

45. Razak, O.A.; Belal, S.F.; Bedair, M.M. J. Pharm. Biomed. Anal. 2003, 31, 701-711.

46. Bonazzi, D.; Gotti, R.; Andrisano, V. J. Pharm. Biomed. Anal. 1997, 16, 431-438.

47. Avadhamulu, A.B.; Pantulu, A.R.R. Indian Drugs 1993, $30,646$.

48. Qin, W.; Zhang, Z.; Tian, Y.; Xu, F. Biomed. Chromatogr. 2007, 21, 415-421.

49. Padua, A.A.F.; Barrientos-Astigarraga, R.E.; Rezende, V.M. $J$. Chromatogr. B 2004, 809, 211-216.

50. Yuan, A.S.; Gilbert, J.D. J. Pharm. Biomed. Anal. 1996, 14(7), 773-781.

51. Shepley, K.; Rocci, M.L.; Patrick, H. J. Pharm. Biomed. Anal. 1988, 6(3), 241-251.

52. Abdel-Fattah, L.; El-Kosasy, A.; Abdel-Aziz, L. J. Am. Sci., 2010, 6(10), 1115-1121.

53. Gustafsson, S.; Erriksson, B.M.; Nilsson, I. J. Chromatogr. 1990, 506, 75-83.

54. Barbato, F.; Morrica, P.; Quaglia, F. II Farmaco, 1994, 49, 457460.

55. Hajnalka, J.; Pettinari, C.; Marchetti, F.; Kamu, E.; Nagy, L.; Troyanov, S.; Pellerito, L. J. Inorg. Biochem. 2003, 97, 370-376.

56. Anvarhusein, I.A.; Wazeer, M.I.M. Spectrochim. Acta Part A 2006, 65, 191-195.

57. Xiaoling, W.; Du, L.; Li, D.; Gong, Q.; Wang, L.; Lin, Y. Spectrochim. Acta Part A 2012, 94, 12-17.

58. Geary, W.J. Coord. Chem. Rev. 1971, 7, 81-122.

59. Kobelnik, M.; Cassimiro, D.L.; Santos, D.D.; Ribeiro, C.A.; Crespi, M.S. Chinese J. Chem. 2011, 29(11), 2271-2277.

60. Refat, M.S. Spectrochim. Acta Part A 2007, 68, 1393-1405.

61. Sadeek, S.A.; El-Didamony, A.M., El-Shwiniy, W.H.; Zordok, W.A. J. Arg. Chem. Soc. 2009, 97, 51-76.

62. Adam, A.A. J. Mat. Sci. Res. 2012, 1, 167-182.

63. Deacon, G.B.; Phillips, R.J. Coord. Chem. Rev. 1980, 33, 227-250.

64. Dendrinou-Samara, C.; Tsotsou, G.; Ekateriniadou, L.V.; Kortsaris, A.H.; Raptopoulou, C.P.; Terzis, A.; Kyriakidis, D.A.; Kessissoglou, D.P. J. Inorg. Biochem. 1998, 71, 171-179.

65. Nakamoto, K. Infrared and Ramman Spectra of Inorganic and Coordination Compounds, (4 ${ }^{\text {th }}$ ed.), New York: Wiley. pp. 230, 1986.

66. Bhattacharyya, S.; Mukhopadhyay, S.; Samanta, S.; Weakley, T.J.R.; Chaudhury, M. Inorg. Chem. 2002, 41, 2433-2440.

67. Nakamoto, K. Infrared Spectra of Inorganic and Coordination Compounds, Wiley Interscience, New York, 1978.

68. Ross, S.D. Inorganic Infrared and Raman Spectra, Mc Graw Hill, London, 1972.

69. Sharma, S.; Iqbal, S.A.; Bhattacharya, M. Orient. J. Chem. 2009, 25(4), 1101- 1104.

70. Refat, M.S. J. Mol. Struct. 2011, 985, 380-390.

71. Freeman, E.S.; Carroll, B. J. Phys. Chem. 1958, 62, 394-397.

72. Coats, A.W.; Redfern, J.P. Nature 1964, 201, 68-69.

73. Horowitz, H.W.; Metzger, G. Anal. Chem. 1963, 35, 1464.

74. Flynn, J.H.F.; Wall, L.A. J. Res. Natl. Bur. Stand. 1966, 70A, 487523.

75. Wendlandt, W.W. Thermal Methods of Analysis, Wiley, New York, 1974.

76. Gupta, R.; Saxena, R.K.; Chatarvedi, P.; Virdi, J.S. J. Appl. Bacteriol. 1995, 78, 378 . 